International Journal of Social Science and Economic Research

ISSN: 2455-8834

Volume: 05, Issue: 05 "May 2020"

\title{
ENVIRONMENTAL DEGRADATION, ENERGY CONSUMPTION AND ECONOMIC GROWTH IN CAMEROON
}

\author{
Ndifor Roger Tah \\ PhD student, University of Buea, SWR Cameroon
}

DOI: 10.46609/IJSSER.2020.v05i05.012 URL:https://doi.org/10.46609/IJSSER.2020.v05i05.012

\begin{abstract}
This study investigated the relationship between environmental degradation, energy consumption and economic growth in Cameroon using time series data ranging from 1970-2018. The study employed the Autoregressive Distributional Lag model (ARDL) procedure to analyze the data with the aid of Econometrics View Package (E- views 10). The results obtained revealed a positive short run as well as long run relationship between energy consumption (energy use) and economic growth (RGDP). Also, there is a positive and significant relationship between electricity consumption and economic growth in both the short run and long run. Again, the results established a negative relationship between environmental degradation $\left(\mathrm{CO}_{2}\right)$ and economic growth (RGDP) in the short run as well as in the long run. Furthermore, the result revealed a positive and significant relationship between energy consumption and $\mathrm{CO}_{2}$ emission in the short run but insignificant in the long run. Lastly, the coefficients of the ARDL error correction mechanism $(\mathrm{ecm}(-1))$ are all negative and statistically significant indicating that the speed of adjustment from the short run to the long equilibrium is significant. Based on the results, the study recommends that companies in charge oil refining and transportation should increase the supply of diesel and petrol around the country by connecting the major towns with oil pipelines. Secondly, the government should increase its budgetary allocation to the energy sector.
\end{abstract}

Keywords: Environmental Degradation, Energy Consumption, Electricity Consumption, Economic growth, Autoregressive Distributional Lag model

\section{INTRODUCTION}

The economic growth of an Economy will require the excessive use of energy and other resources, which contributes to rising environmental degradation. According to Shama (2014), the desire for growth has led to increased levels of human activities in both the urban and rural 


\section{International Journal of Social Science and Economic Research}

ISSN: $2455-8834$

Volume: 05, Issue: 05 "May 2020"

areas which have greatly contributed to global warming and climate change that continues to threaten the survival of living organisms. Over the years, the world has been experiencing expansions in industries, urban areas and population size which has resulted in deforestation and increase in the use of energy especially fossil fuel. These resulted to changes in lifestyles which have contributed to climatic changes, thus, attracting considerable worldwide attention (Sharma, 2011). The rise in greenhouse gasses emissions has been the major ongoing concern for both developed and developing countries.

According to Chibuzor A. (2018), the increasing level of global temperatures and climatic changes has been the major topic of debate for most countries, be it in the developed or developing countries. Most developing countries have put in place development plans or visions for economic growth and emergence which requires the exhaustive use of energy and other resources, thus contributing to rising environmental degradation. Report from the Intergovernmental Panel on Climate Change (IPCC, 2007), indicated that combustion of fossil fuel for heat supply, electricity generation and transport account for about $70 \%$ of total emissions including carbon dioxide, methane and nitrous oxide. According to IPCC (2007), the global mean surface temperature did rise by $0.74^{\circ} \mathrm{C}$ between 1906 and 2005 .

According to the World Bank (2007), carbon dioxide remains the major greenhouse gas emission and represents $58.8 \%$ of total greenhouse emissions. The international community together with some international organizations around the world have made continuous attempt to reduce green house emissions and consequently global temperatures. One of which was the Kyoto Protocol agreement which took place in 1997 on the theme "the United Nations Framework Convention on Climate Change" (UNFCCC). Its main objective was that of reducing greenhouse gasses (GHG) emissions to 5.2\% during the period 2008-2012, which was expected to be lower than the levels of 1990.

According to a report on global energy and carbon emission by the international energy agency (IEA, 2018), global energy related $\mathrm{CO}_{2}$ emissions rose by $1.4 \%$ with an increase of 460 million tonnes (Mt), and reached a historic high of 32.5 giga tones $(\mathrm{Gt})$ in 2017. The increase in carbon emissions, which is equivalent to emissions from 170 million additional cars, was as a result of the global economic growth of 3.7\%, lower fossil-fuel prices and weaker energy efficiency efforts. These three factors contributed to push up global energy demand by $2.1 \%$ in 2017 .

Empirical studies over the years have proven that in order to increase economic growth, more energy needs to be consumed and this will increase the level of $\mathrm{CO}_{2}$ emission which in the long run, governments will have to reduce their energy consumption levels, so as to curb the negative consequences of climate change. Environmental degradation may have negative effects on 


\section{International Journal of Social Science and Economic Research}

ISSN: $2455-8834$

Volume: 05, Issue: 05 "May 2020"

economic development through several channels, such as migration, economic growth, health, conflicts and agriculture.

In a study carried out by Tamba et al (2012), they indicated that the increase in the number of vehicles used resulted in a continuous growth in the consumption of fuel in Cameroon. This has contributed to increasing the level of GHG emissions. Their findings revealed that during the period 1995-2008, GHG emissions increased by about 51\%. Cameroon's road transport sector alone emitted into the atmosphere an average of 1421.4 kilotons of $\mathrm{CO}_{2}$ per year from gasoline and diesel consumption. $\mathrm{CO}_{2}$ emissions from the road transport sector in Cameroon stood at $34.33 \%$ of total $\mathrm{CO}_{2}$ emissions. Despite having one of the most diversified economies in the CEMAC region, Cameroon's economic activity slowed down in 2016. The economy was expected to grow by $3.7 \%$ by the end of 2017 , compared to $4.4 \%$ in 2016 . However, the global drop in oil prices led to an economic slowdown. In 2017, GDP growth stood at 4\%, brought down by the decrease in oil production and the fall in demand.

Cameroon is a country in Sub Saharan African which is endowed with many natural resources such as oil deposits, timber, hydroelectric power, natural gas, cobalt, nickel, iron ore, uranium and many others. Despite all of these, Cameroon's growth performance has not been very good. In fact, over the years, agriculture has been the pillar of the economy. The agricultural sector alone provides employment to about $80 \%$ of the labour force. It also contributes about one third of the GDP and three quarters of total export earnings. Diesel consumption has been noted to have a direct impact on environmental pollution level. Cameroon is experiencing a rising demand for energy, particularly petroleum products. This is due to the construction of facilities that were to host the Africa Cup of Nations (CAN) 2019 which generated greater demand for petroleum products, especially diesel. High economic growth requires the implementation of large industrial projects using heavy machineries which will result in high energy consumption and this is responsible for higher levels of $\mathrm{CO}_{2}$ emissions which is a potential threat to the ecosystem. How then can economic growth be more sustainable remains a major challenge. This situation results in a dilemma between energy consumption and economic growth. If energy consumption led to economic growth which negatively affects the environment, it implies that, policies aimed at reducing energy consumption to protect the ecosystem will negatively affect economic growth. How can the government pursue economic growth without increasing carbon dioxide emissions through an increase in energy consumption? Policy makers therefore need more evidence to assist in the process of making rational economic decisions, since there are only few studies on Cameroon's energy economics. It is therefore essential to investigate the relationship between environmental degradation, energy consumption and economic growth in Cameroon in order to put in place mitigation mechanisms. This study is aim at (1) examining the determinants of environmental degradation ( $\mathrm{CO}_{2}$ emission) (2) investigating the factors that affect 


\section{International Journal of Social Science and Economic Research}

ISSN: $2455-8834$

Volume: 05, Issue: 05 "May 2020"

energy consumption and (3) analyzing the effect of energy consumption and environmental degradation on economic growth in Cameroon.

The rest of this paper is organized as follows; in Section two, the relevant literature is reviewed. Section three presents the analytical techniques. Results are presented and discussed in the fourth Section. The fifth section summarizes, recommends and draws an adequate conclusion from the study.

\section{EMPIRICAL REVIEW}

The relationship between energy consumption, environmental degradation and economic growth has been examined for developed countries as well as developing countries over different periods with different methodologies and areas of study. The results obtained by different researchers at different period of time are almost the same but the direction of causation of this relationship remains controversial. This difference in results is largely due to the use of different econometric methods and time periods, besides country-specific heterogeneity in climatic conditions, economic development and energy consumption patterns, among other things. As per the need of this study, a review of selected literature is examined as follows;

Uddin and Abdul Wadud (2014) carried out a study to examine the causal relationship between carbon emissions and economic growth in seven SAARC countries. They made use of time series data ranging from 1972 to 2012. Also, they use Vector Error Correction Modelling (VECM) approach along with the Augmented Dickey Fuller (ADF) and Phillips-Perron (P.P) test. Johansen's cointegration test was used to check time series properties and to determine the long run relationship between the variables. Their results indicated a long run relationship between environmental pollution and economic growth. Also, their result reviews that the estimated coefficients of carbon dioxide emissions is positive and significant, thus, having a significant impact on GDP in the long run.

In this same light, Holtz (1995), were also out to examine the relationship between $\mathrm{CO}_{2}$, and economic growth. Using Vector Error Correction Modelling (VECM) and Johansen's cointegration test, their results revealed that the ratio between $\mathrm{CO}_{2}$ emissions and income never turned downwards although there was a slower growth of $\mathrm{CO}_{2}$ at high-income levels. Based on their findings, their conclusion regarding global economic growth and $\mathrm{CO}_{2}$ emissions was pessimistic. That is, if this relationship between $\mathrm{CO}_{2}$, and economic growth exist in the future, then the level of carbon dioxide emissions will increases. According to this study, increases in population will contribute to the growth of the GDP and this will increase the propensity to emit.

Khalid et al. (2012) carried out a research on economic growth, $\mathrm{CO}_{2}$ emissions, energy 


\section{International Journal of Social Science and Economic Research}

ISSN: $2455-8834$

Volume: 05, Issue: 05 "May 2020"

consumption and the employment ratio. They made use of the ARDL and VECM test techniques to establish the long run and short run relationships between economic growth, $\mathrm{CO}_{2}$ emissions and energy consumption in Saudi Arabia. Their results show that there exist both a long run and short run relationship among the variables in the model. Based on their regression results, the coefficients of elasticity for $\mathrm{CO}_{2}$ emissions, energy consumption, and employment ratio were all positive having significant effects on GDP in the long run. The results for direction of causality reviewed that neither carbon dioxide emissions per capita nor energy consumption per capita affects GDP per capita, but employment ratio affect GDP per capita in the short run.

Akinlo (2008) examined the effect of energy consumption on economic growth in Cameroon. He used an Autoregressive Distributed Lag (ARDL) bounds model. The findings revealed that there exists a long run relationship between energy consumption and economic growth in Cameroon, Cote D'Ivoire, Gambia, Ghana, Senegal, Sudan and Zimbabwe. Also, this result found that the coefficient of energy consumption is positive and significant. This means that energy consumption has a positive long run relationship on economic growth in Ghana, Kenya, Senegal and the Sudan. The findings also show a bi-directional relationship between energy consumption and economic growth for Gambia, Ghana and Senegal.

Ansgar et al. (2010) were out to examine the long-run relationship between energy consumption and real GDP for 25 OECD countries from 1981 to 2007. Making use of principal component analysis, they made a distinction between common factors and idiosyncratic components. This was carried out to distinguish between developments on an international level and at national level as drivers of the long-run relationship. Their cointegration results indicate the existence of a long-run relationship between energy consumption and real GDP. They found out that energy consumption is price-inelastic or does not change as its price changes. Their results also indicated that there is a bi-directional causal relationship between energy consumption and economic growth. Based on this finding, it could be concluded that energy policies at the national level may not have a large impact if international developments contribute more to the relationship between energy consumption and economic growth.

Menyah and Worlde (2010) were out to examine the relationship between energy consumption, pollutant emissions and economic growth in South Africa. The study made use of the Bound Test for Cointegration. This study covers the period from 1965 to 2006. Their result shows that there are short and long run relationships between pollutant emission and economic growth. Furthermore, the Granger causality test revealed unidirectional causality running from carbon emission to economic growth, from energy consumption to economic growth and from energy consumption to $\mathrm{CO}_{2}$ emission. They concluded that South Africa has to forgo its economic growth or reduce its energy consumption per unit of output or both in order to reduce pollutant 


\section{International Journal of Social Science and Economic Research}

ISSN: $2455-8834$

Volume: 05, Issue: 05 "May 2020"

emission.

Mohammed et al. (2012) carried out another research on energy, consumption carbon emission and economic growth nexus in Bangladesh. They used time series data from the period 1972 to 2006. Their study made use of Johansen bivariate cointegration technique and ARDL. They also tested for causality using vector error correction model. Their results show that $\mathrm{CO}_{2}$ causes Economic growth both in the short and long run. Their findings also indicated that the direction of causality runs from energy consumption to economic growth both in the short and long run.

Tamba (2017) also carried out a study on "Energy consumption, economic growth, and CO2 emissions: Evidence from Cameroon". He used annual time-series data ranging from the period 1971 to 2013. Making use of the cointegration test and Granger causality based on the error correction model (ECM), the results confirm the presence of a long-run equilibrium relationship between Energy consumption, economic growth, and $\mathrm{CO} 2$ emissions. The Granger causality based on ECM indicates the existence of three bidirectional relationships in the long run at the $5 \%$ level between the variables. There however exists only one unidirectional relationship at the $5 \%$ level of significance running from $\mathrm{CO} 2$ emissions to energy consumption in the short run. He ended up by concluding that Cameroons hould implement policies to maintain the rise in energy consumption while developing energy-saving technologies and increase the renewable energy sources.

This paper is different from previous contributions because its employs the autoregressive distributional lag model (ARDL) to overcome the problem of endogeneity which other studies on the Cameroonian economy have not addressed.

\section{METHODOLOGY}

This study covers a period of 48 years, running from 1970-2018 inclusive. This is so because most of the data needed for the study was available within this period for the chosen country under study. The study used secondary data. Energy use and electricity consumption data were obtained from the statistics of International Energy Agency (IEA), while carbon dioxide, GDP per capital, Labour force, Urbanisation and gross fixed capital formation data was obtained from the World Bank database (WDI 2019).

The empirical model used for this study is designed to investigate the relationship between energy consumption, environmental degradation and economic growth in Cameroon is anchored on the theoretical framework of Solow (1956). The Solow model focuses on four variables: Output (Y), Capital (K), labour (L), and "knowledge" or the effectiveness of labour (A). At any point, the economy has some amount of capital, labour and knowledge Romer (2009). These are 
combines to produce output. The production function takes the form:

$Y(t)=f(K(t), A(t), L(t))$

$\mathrm{Y}(\mathrm{t})=$ output at time $\mathrm{t}, \mathrm{K}(\mathrm{t})=$ capital at time $\mathrm{t}, \mathrm{L}(\mathrm{t})=$ labour at time $\mathrm{t}$,

$\mathrm{A}(\mathrm{t})=$ knowledge at time $\mathrm{t}$.

$A(t)$ and $L(t)$ enter the model multiplicatively, hence $A(t) L(t)$ is effective labour. Hence, the specific example of production function is the Cobb Douglas function. Ang (2008), Sharma (2010), Menyah and Wolde-Rufael (2010), and Shahbaz et al. (2012), among others, included energy and $\mathrm{CO} 2$ emissions variables in their empirical model to examine the impact of these two variables on economic growth. Introducing other variables into the above Solow model gives the following ARDL equations;

The autoregressive distributional lag model (ARDL $(\mathrm{p}, \mathrm{q})$ model) can be specified as:

$\Delta \mathrm{Y}_{\mathrm{t}}=\mathrm{c}_{\mathrm{o}}+\sum_{i=1}^{p} c_{1} \Delta \mathrm{Y}_{\mathrm{t}-1}+\sum_{i=1}^{q} \delta \Delta \mathrm{X}_{\mathrm{t}-1}+\phi_{1} \mathrm{Y}_{\mathrm{t}-1}+\phi_{2} \mathrm{X}_{\mathrm{t}-1}+\mathrm{e}_{1}$

\section{Carbon dioxide emission equation}

$\Delta \mathrm{LCO}_{\mathrm{t}}=\alpha_{\mathrm{o}}+\sum_{i=1}^{p} a_{1} \Delta \mathrm{LCO}_{2 \mathrm{t}-1}+\sum_{i=1}^{q} a_{2} \Delta \Delta \mathrm{URB}_{\mathrm{t}-1}+\sum_{i=1}^{q} a_{3} \Delta \mathrm{LEU}_{\mathrm{t}-1}+\sum_{i=1}^{q} a_{4} \Delta \mathrm{LRGDP}_{\mathrm{t}-1}+\sum_{i=1}^{q} a_{5}$ $\Delta \mathrm{LGFCF}_{\mathrm{t}-1}+\mathrm{A}_{1} \mathrm{LCO}_{2 \mathrm{t}-1}+\mathrm{A}_{2} \mathrm{URB}_{\mathrm{t}-1}+\mathrm{A}_{3} \mathrm{LEU}_{\mathrm{t}-1}+\mathrm{A}_{4} \mathrm{LRGDP}_{\mathrm{t}-1}+\mathrm{A}_{5} \mathrm{LGFCF}_{\mathrm{t}-1}+$

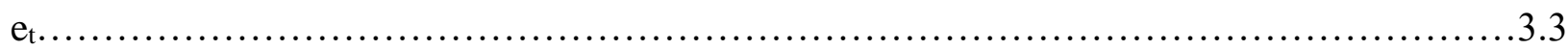

\section{Energy consumption equation}

$\Delta \mathrm{LEU}_{\mathrm{t}}=\mathrm{b}_{\mathrm{o}}+\sum_{i=1}^{p} b_{1} \Delta \mathrm{LEU}_{\mathrm{t}-1}+\sum_{i=1}^{q} b_{2} \Delta \mathrm{LECON}_{\mathrm{t}-1}+\sum_{i=1}^{q} b_{3} \Delta \mathrm{LCO}_{2 \mathrm{t}-1}+\sum_{i=1}^{q} b_{4} \Delta \mathrm{LRGDP}_{\mathrm{t}-1}+\sum_{i=1}^{q} b_{5}$ $\Delta \mathrm{LGFCF}_{\mathrm{t}-1}+\sum_{i=1}^{q} b_{6} \Delta \mathrm{LLF}_{\mathrm{t}-1}+\mathrm{B}_{1} \mathrm{LEU}_{\mathrm{t}-1}+\mathrm{B}_{2} \mathrm{LECON}_{\mathrm{t}-1}+\mathrm{B}_{3} \mathrm{LCO}_{2 \mathrm{t}-1}+\mathrm{B}_{4} \mathrm{LRGDP}_{\mathrm{t}-1}+\mathrm{B}_{5}$

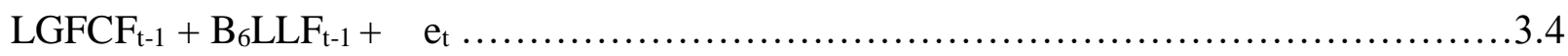

\section{Economic growth equation}

$\Delta \mathrm{LRGDP}_{\mathrm{t}}=\mathrm{c}_{\mathrm{o}}+\sum_{i=1}^{p} c_{1} \Delta \mathrm{LRGDP}_{\mathrm{t}-1}+\sum_{i=1}^{q} c_{2} \Delta \mathrm{LECON}_{\mathrm{t}-1}+\sum_{i=1}^{q} c_{3} \Delta \mathrm{LEU}_{\mathrm{t}-1}+\sum_{i=1}^{q} c_{4} \Delta \mathrm{LCO}_{2 \mathrm{t}-1}+$ 
International Journal of Social Science and Economic Research

ISSN: $2455-8834$

Volume: 05, Issue: 05 "May 2020"

$\sum_{i=1}^{q} c_{5} \Delta \mathrm{LGFCF}_{\mathrm{t}-1}+\sum_{i=1}^{q} c_{6} \Delta \mathrm{LLF}_{\mathrm{t}-1}+\mathrm{C}_{1} \mathrm{LRGDP}_{\mathrm{t}-1}+\mathrm{C}_{2} \mathrm{LECON}_{\mathrm{t}-1}+\mathrm{C}_{3} \mathrm{LEU}_{\mathrm{t}-1}+\mathrm{C}_{4} \mathrm{LCO}_{2 \mathrm{t}-1}+\mathrm{C}_{5}$

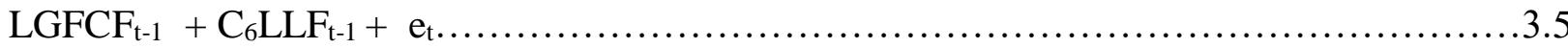

Where;

LRGDP $=\log$ of Per capita real GDP (measured at 2010 constant US dollars)

LECON $=\log$ of Electricity Power Consumption (kWh per capita)

$\mathrm{LEU}=\log$ of Energy use ( $\mathrm{kg}$ of oil equivalent per capita)

$\mathrm{LCO}_{2}=\log$ of $\mathrm{CO}_{2}$ emission (measured in metric tons per capita)

LGFCF $=\log$ of Gross Fixed Capital Formation (constant 2010 US\$)

$\mathrm{LLF}_{\mathrm{t}}=\log$ of Labour Force (Population ages 15-64, total)

$\mathrm{c}_{0}=$ Constant term, $\mathrm{c}_{1}=$ RGDP coefficient, $\mathrm{c}_{2}=$ ECON coefficient, $\mathrm{c}_{3} \mathrm{EU}=$ coefficient, $\mathrm{c}_{4}=$ $\mathrm{CO}_{2}$ coefficient, $\mathrm{c}_{5}=$ GFCF coefficient, $\mathrm{c}_{6}=\mathrm{LF}$ coefficient. . $(\mathrm{c}=$ short run coefficients and $\mathrm{C}=$ Long run coefficients).

$\Delta=$ First difference parameter

$\phi=$ Speed or rate of adjustment

$\mathrm{p}=$ lags used for the dependent variable

$\mathrm{q}=$ lags used for the independent (exogenous) variables

$\mathrm{e}=$ White Noise Disturbance Error Term.

A priori $\mathrm{a}_{0}>0, \mathrm{a}_{1}>0, \mathrm{a}_{2}>0, \mathrm{a}_{3}>0, \beta_{0}>0, \beta_{1}>0, \beta_{2}>0, \beta_{3}>0, \mathrm{C}_{0}>0, \mathrm{C}_{1}>0, \mathrm{C}_{2}>0, \mathrm{C}_{3}>0, \mathrm{C}>0, \mathrm{C}_{5}>0$

These a priori are coefficients of variables which were estimated and their signs were derived from economic theory.

The models for energy consumption, $\mathrm{Co}_{2}$ emission and economic growth were estimated using the Autoregressive Distributed Lag (ARDL) cointegration procedure proposed by Pesaran et al (2001). The autoregressive distributional lag model (ARDL) is a model in which the dependent variable is a function of its lagged values, the current and lagged values of other exogenous variables in the model. The ARDL model can also be seen as a form of unrestricted error correction model (ECM) because all the long run relationship variables are specified but not restricted. This model is use when we have a group of time series in which some variable(s) are level stationary 1(0) and others are stationary after their first difference 1(1) but none of the variable(s) must be stationary after their second differencing 1(2). The study fulfilled the above condition; in this case, we use the ARDL bounds test to verify if short run and long run relationship exist between energy use, $\mathrm{Co}_{2}$ emissions, gross domestic product per capital and other variables included in the model. Also, the application of ARDL produces unbiased 
estimates of long-run model.

\section{PRESENTATION AND DISCUSSION OF RESULTS}

Table 4.1: Correlation Analysis of Variables used in the Study

\begin{tabular}{|c|c|c|c|c|c|c|c|}
\hline & LCO $_{2}$ & LECON & LEU & LGFCF & LLF & LRGDP & URB \\
\hline LCO & & 1.0000 & & & & & \\
\hline LECON & $\begin{array}{c}0.2890 \\
(0.0705)\end{array}$ & 1.0000 & & & & & \\
\hline LEU & $\begin{array}{c}0.0921 \\
(0.5721)\end{array}$ & $\begin{array}{c}-0.6460^{*} \\
(0.0000)\end{array}$ & 1.0000 & & & & \\
\hline LGFCF & $\begin{array}{c}0.3721 \\
(0.0180)\end{array}$ & $\begin{array}{c}0.7394^{*} \\
(0.0000)\end{array}$ & $\begin{array}{c}-0.4323 \\
(0.0053)\end{array}$ & 1.0000 & & & \\
\hline LLF & $\begin{array}{c}-0.0794 \\
(0.6262)\end{array}$ & $\begin{array}{c}0.5561^{*} \\
(0.0002)\end{array}$ & $\begin{array}{c}-0.8210^{*} \\
(0.0000)\end{array}$ & $\begin{array}{c}0.5452^{*} \\
(0.0003)\end{array}$ & 1.0000 & & \\
\hline LRGDP & $\begin{array}{c}0.4265 \\
(0.0061)\end{array}$ & $\begin{array}{c}0.4350 \\
(0.0050)\end{array}$ & $\begin{array}{c}0.2265 \\
(0.1599)\end{array}$ & $\begin{array}{c}0.6542^{*} \\
(0.0000)\end{array}$ & $\begin{array}{c}-0.2278 \\
(0.1575)\end{array}$ & 1.0000 & \\
\hline URB & $\begin{array}{c}-0.0661 \\
(0.6854)\end{array}$ & $\begin{array}{c}0.5553^{*} \\
(0.0002)\end{array}$ & $\begin{array}{c}-0.7750^{*} \\
(0.0000)\end{array}$ & $\begin{array}{c}0.5596^{*} \\
(0.0002)\end{array}$ & $\begin{array}{c}0.9945^{*} \\
(0.0000)\end{array}$ & $\begin{array}{c}-0.1955 \\
(0.2267)\end{array}$ & 1.0000 \\
\hline
\end{tabular}

$*=$ significant at $1 \%$. Figures in brackets ( ) represent probability-values of the correlation coefficient which is use to determine if the coefficients are significant or not.

\section{Source: Computed by author using E-views 10.}

Table 4.1 above is the correlation matrix table that shows the degree of correlation between the variables under study. The table shows how the variables used are related to one another and to itself. An examination of the values in the table shows that there is no perfect correlation among the set of variables used in this study. The only perfect correlation is between one variable and itself which is normal. 
International Journal of Social Science and Economic Research

ISSN: $2455-8834$

Volume: 05, Issue: 05 "May 2020"

Table 4.2: Augmented Dickey-Fuller test for unit root

\begin{tabular}{|c|c|c|c|c|c|c|c|c|c|c|c|}
\hline \multirow{3}{*}{$\begin{array}{l}\text { Variabl } \\
\text { es }\end{array}$} & \multirow{2}{*}{\multicolumn{2}{|c|}{ in level }} & \multicolumn{3}{|c|}{ Critical values } & \multirow{2}{*}{\multicolumn{2}{|c|}{$1^{\text {st }}$ difference }} & \multicolumn{3}{|c|}{ Critical values } & \multirow{3}{*}{$\begin{array}{l}\begin{array}{l}\text { Order } \\
\text { of }\end{array} \\
\text { integr } \\
\text { ation } \\
\end{array}$} \\
\hline & & & \multirow[t]{2}{*}{$1 \%$} & \multirow[t]{2}{*}{$5 \%$} & \multirow[t]{2}{*}{$10 \%$} & & & \multirow[t]{2}{*}{$1 \%$} & \multirow[t]{2}{*}{$5 \%$} & \multirow[t]{2}{*}{$10 \%$} & \\
\hline & $\begin{array}{l}\text { T- } \\
\text { Statisti } \\
\text { cs }\end{array}$ & PROB & & & & $\begin{array}{l}\text { T- } \\
\text { STATIS } \\
\text { TICS }\end{array}$ & $\overline{\text { PROB }}$ & & & & \\
\hline $\mathrm{LCO}_{2}$ & -3.408 & 0.0159 & -3.589 & -2.930 & -2.603 & -7.020 & 0.0000 & -3.597 & -2.933 & -2.605 & $\mathrm{I}(1)$ \\
\hline Lecon & -1.011 & 0.741 & -3.592 & -2.931 & 2.604 & -5.620 & 0.0000 & -3.597 & -2.933 & -2.605 & $\mathrm{I}(1)$ \\
\hline Leu & 0.358 & 0.977 & -3.601 & -2.935 & -2.606 & -5.152 & 0.0001 & -3.601 & -2.935 & -2.606 & $\mathrm{I}(1)$ \\
\hline Lrgdp & -3.294 & 0.0210 & -3.585 & -2.928 & -2.602 & -4.493 & 0.0007 & -3.578 & -2.925 & -2.601 & $\mathrm{I}(1)$ \\
\hline LIf & -7.305 & 0.000 & -4.161 & -3.506 & -3.183 & & & & & & $\mathrm{I}(0)$ \\
\hline Lgfef & -1.796 & 0.3771 & -3.597 & -2.933 & -2.605 & -4.018 & 0.0032 & -3.597 & -2.933 & -2.605 & $\mathrm{I}(1)$ \\
\hline Urb & -5.167 & 0.0006 & -4.171 & -3.511 & -3.186 & & & & & & $1(0)$ \\
\hline
\end{tabular}

\section{Source: Computed by author using E-views 10.}

As shown on table 4.2, the null hypothesis of non-stationarity of the time series was investigated by employing the Augmented Dickey-Fuller (ADF) test. A variable is said to be stationary when the absolute value of its statistical test is greater than its critical value. $\mathrm{Co}_{2}$ emission is stationary as the absolute value of its statistical test is less than the critical value at even at $1 \%$ level of significance. Energy use and Electricity consumption also follow suit because their test statistic is less than their critical values at even at $1 \%$ level of significance. In addition, real gdp, labour force and gross fixed capital formation are all stationary as shown on table 4.2 as the absolute values of their test statistic are less than their critical values even at $1 \%$ level of significance. Urbanization is stationary even without differencing. Based on this test, the null hypothesis (variables are not stationary) is rejected while the alternative (variables are stationary) is retained. 
International Journal of Social Science and Economic Research

ISSN: 2455-8834

Volume: 05, Issue: 05 "May 2020"

Table 4.3: ARDL bounds testing procedure for carbon emission equation (Selected Model: ARDL $(1,0,1,2,1,2)$ )

\begin{tabular}{|l|l|l|l|l|}
\hline Test statistics & Value & Significant & $\mathbf{1 ( 0 )}$ & $\mathbf{1 ( 1 )}$ \\
\hline F-statistics & 7.0417 & $10 \%$ & 2.08 & 3 \\
\hline & & $5 \%$ & 2.39 & 3.38 \\
\hline & & $2.5 \%$ & 2.7 & 3.73 \\
\hline & & $1 \%$ & 3.06 & 4.15 \\
\hline
\end{tabular}

\section{Source: Computed by author using E-views 10.}

The bound test result presented on the above table shows evidence of a long run relationship between the dependent variable $\left(\mathrm{CO}_{2}\right.$ emission) and the independent variables (electricity consumption, energy use, gross fixed capital formation, gross domestic product per capita and Urbanization). This is seemed as the calculated F statistic (7.0417) is greater than the critical values of the upper level of the bound (4.15) at $1 \%$ level of significance. since the F statistic exceeds the upper bound of the critical value band, the null hypothesis of no long run relationship between the variables is rejected Based on the above bound test result which shows evident of a long run relationship between $\mathrm{co}_{2}$ emission, electricity consumption, energy use, gross fixed capital formation, gross domestic product per capita and Urbanization.

Table 4.4: ARDL long run estimation result for carbon emission equation (Selected Model: ARDL $(1,0,1,2,1,2)$ )

\begin{tabular}{|c|c|c|c|}
\hline Variable & Coefficient & Standard Error & Prob \\
\hline LEU & 0.1933 & 1.7659 & 0.9137 \\
\hline LGFCF & $3.6467 *$ & 1.3398 & 0.0116 \\
\hline LRGDP & $-9.4961 * *$ & 3.0093 & 0.0041 \\
\hline URB & $-0.1970 *$ & 0.0728 & 0.0121 \\
\hline C (cons) & $-17.1290 * *$ & 2.601109 & 0.003 \\
\hline Obs & 38 & & \\
\hline
\end{tabular}

** denote $5 \%$ and $*$ denote $10 \%$ levels of significant

Source: Computed by author using E-views 10.

The results presented on the above table shows that there is a long run positive relationship between energy use and $\mathrm{CO}_{2}$ emissions even though this relationship is not statistically 
significant. This is observed by the positive sign of the coefficient of energy use which is 0.1934 , meaning that a $1 \%$ increase in the energy use will result to a $0.1934 \%$ increase in $\mathrm{CO}_{2}$ emissions. This result is in agreement with the economic expectation. Again, the coefficient of gross domestic capital formation is positive (3.6467). This means that positive changes in capital formation will result to positive changes in $\mathrm{CO}_{2}$ emissions. For example, a $1 \%$ increase in gross capital formation will led to $3.6467 \%$ increase in $\mathrm{CO}_{2}$ emissions. This result is in line with economic expectations and it is statistically significant at $10 \%$ level of significant. As such, gross capital formation is an important factor which must be considered formulating environmental policies in Cameroon.

Table 4.5: ARDL Error Correction Regression results for carbon emission equation (Selected Model: ARDL (1, 0, 1, 2, 1, 2))

\begin{tabular}{|c|c|c|c|}
\hline Variable & Coefficient & Standard Error & Prob \\
\hline D(LEU) & $3.488443 *$ & 1.898672 & 0.0781 \\
\hline D(LGFCF) & -0.171550 & 0.585636 & 0.7720 \\
\hline D(LGFCF(-1)) & $-2.225738 *$ & 0.519501 & 0.0002 \\
\hline D(LRGDP) & $-1.668726 * *$ & 1.697231 & 0.3349 \\
\hline D(URB) & $2.323813 *$ & 0.592222 & 0.0015 \\
\hline D(URB(-1) & -1.962620 & 0.548520 & 0.0000 \\
\hline CointEq(-1)* & $-0.912557 * * *$ & 0.116724 & \\
\hline R-Square & 0.687236 & & \\
\hline Adj R-squared & 0.626701 & & \\
\hline Durbin-Watson & 2.053221 & & \\
\hline \multicolumn{2}{|c|}{38} & & \\
\hline Ob* denote $1 \%, * *$ denote $5 \%$ and $*$ denote $10 \%$ levels of significant & \\
\hline
\end{tabular}

Source: Computed by author using E-views 10.

The table above shows the ardl error correction mechanism (ECM) which was employed to check the short run relationship among the variables. The results show that the coefficient of ECM (-1) is significant at $1 \%$ level which indicate that the speed of adjustment from short run to long run is significant. More specifically, the coefficient of the error correction term is -0.9126 meaning that when the per capita carbon dioxide emission is above or below its equilibrium 
level, it adjusts by almost $91 \%$ per year. Again, in the short run, energy use has a positive coefficient of 3.884 which shows a positive relationship between energy use and $\mathrm{CO}_{2}$ emission. This is statistically significant at $10 \%$ level of significant. This result further reveals that in the short run, $\mathrm{CO}_{2}$ emission does not respond well in respect of gross fixed capital formation. This is because the long run elasticity of $\mathrm{CO}_{2}$ emission with respect to gross fixed capital formation (3.6467) is higher than short run elasticity of (-0.1716). Athough the relationship between energy use and $\mathrm{CO}_{2}$ emission are statistically insignificant, the relationship between the one year lag values of energy use and $\mathrm{CO}_{2}$ emission is statistically significant at $1 \%$. This means that over time higher gross fixed capital formation in Cameroon will give rise to more $\mathrm{CO}_{2}$ emissions. The short run result shows a positive relationship between rate of urbanization and $\mathrm{CO}_{2}$ emission. This is evident since urbanization rate has a coefficient of 2.3257 meaning that, a $1 \%$ increase in the rate of urbanization will led to a $2.3238 \%$ increased in $\mathrm{CO}_{2}$ emission but the coefficient of the one year lag of the rate of urbanization is negative and significant.

Table 4.6: ARDL bounds testing procedure for energy use equation

\begin{tabular}{|l|l|l|l|l|}
\hline Test statistics & Value & Significant & $\mathbf{1 ( 0 )}$ & $\mathbf{1 ( 1 )}$ \\
\hline F-statistics & 5.2548 & $10 \%$ & 2.08 & 3 \\
\hline $\mathrm{K}$ & 5 & $5 \%$ & 2.39 & 3.38 \\
\hline & & $2.5 \%$ & 2.7 & 3.73 \\
\hline & & $1 \%$ & 3.06 & 4.15 \\
\hline
\end{tabular}

Source: Computed by author using E-views 10.

The bound test result presented on table 4.7 above shows that there exist a long run relationship between the dependent variable (energy use) and the independent variables (electricity consumption, $\mathrm{CO}_{2}$ emission, gross fixed capital formation, gross domestic product per capita and labour force

Table 4.7: ARDL long run estimation results for energy use equation.

Selected Model: ARDL (2, 0, 2, 1, 2, 1)

Dependent variable: Energy use

\begin{tabular}{|c|c|c|c|}
\hline Variable & Coefficient & Standard Error & Prob \\
\hline $\mathrm{LCO}_{2}$ & -0.013932 & 0.017713 & 0.4389 \\
\hline $\mathrm{LLF}$ & $-0.465249^{* *}$ & 0.133296 & 0.0018 \\
\hline LGFCF & $0.225946^{*}$ & 0.111678 & 0.0539 \\
\hline
\end{tabular}


International Journal of Social Science and Economic Research

ISSN: $2455-8834$

Volume: 05, Issue: 05 "May 2020"

\begin{tabular}{|c|c|c|c|}
\hline LRGDP & -0.354633 & 0.281390 & 0.2192 \\
\hline LECON & $-0.182380^{*}$ & 0.085843 & 0.0437 \\
\hline C (cons) & $11.21786^{* * *}$ & 1.370553 & 0.0000 \\
\hline Obs & 39 & & \\
\hline
\end{tabular}

Source: Computed by author using E-views 10.

The value of carbon dioxide emission $\left(\mathrm{CO}_{2}\right)$ is negative and this is in conformity with the a priori expectation. This means that as the growth rate of carbon dioxide emission $\left(\mathrm{CO}_{2}\right)$ increases, the amount of energy consume will decrease. Precisely a $1 \%$ increase in carbon dioxide emission $\left(\mathrm{CO}_{2}\right)$ will lead to a $0.0139 \%$ decrease in energy consumption. Electricity consumption has a negative long run coefficient of -0.1824 . This is not in conformity with our economic a priori expectation.. Gross fixed capital formation (LGFCF) has a positive coefficient of 0.2260 . This implies that as Gross fixed capital formation increases in the long run, the energy use will also increase. Examining the influence of labour force on energy consumption reveals that the coefficient of labour force is negative (-0.4652). This is not in agreement with apriori expectation. This implies that, as labour force increases, the demand for energy will also decrease. A $1 \%$ increase labour force will result in $0.04652 \%$ increase in energy consumption. This result is statistically significant at $5 \%$.

Table 4.8: ARDL Error Correction Regression results for energy use equation

Selected Model: ARDL $(2,0,2,1,2,1)$ selected based on Akaike Information Criterion Dependent variable is Energy use (LEU)

\begin{tabular}{|c|c|c|c|}
\hline Variable & Coefficient & Standard Error & Prob \\
\hline $\mathrm{D}(\mathrm{LEU}(-1)$ & $0.321351^{*}$ & 0.110513 & 0.0075 \\
\hline $\mathrm{D}(\mathrm{LECON})$ & -0.01789 & 0.036331 & 0.6874 \\
\hline $\mathrm{D}(\mathrm{LECON}(-1))$ & 0.063200 & 0.040486 & 0.1311 \\
\hline $\mathrm{D}(\mathrm{LGFCF})$ & 0.037326 & 0.030903 & 0.2384 \\
\hline $\mathrm{D}(\mathrm{LRGDP})$ & -0.106168 & 0.079405 & 0.1933 \\
\hline $\mathrm{D}(\mathrm{LRGDP}(-1))$ & $-0.146784^{*}$ & 0.055749 & 0.0143 \\
\hline
\end{tabular}


International Journal of Social Science and Economic Research

ISSN: 2455-8834

Volume: 05, Issue: 05 "May 2020"

\begin{tabular}{|c|c|c|c|}
\hline $\mathrm{D}(\mathrm{LLF})$ & $11.27355^{* * *}$ & 1.689378 & 0.0000 \\
\hline CointEq(-1)* & $-0.572919^{* * *}$ & 0.084831 & 0.0000 \\
\hline R-Square & 0.663942 & & \\
\hline Adj R-squared & 0.588057 & & \\
\hline Durbin-Watson & 1.86415 & & \\
\hline Obs & 38 & & \\
\hline
\end{tabular}

$* * *$ denote $1 \%, * *$ denote $5 \%$ and $*$ denote $10 \%$ levels of significant

\section{Source: Computed by author using E-views 10.}

The ARDL error correction mechanism (ECM) was estimated to examine the short run relationship among the variables. From the results presented on table 4.8 above, the coefficient of ECM (-1) is significant at $1 \%$ level which indicate that the speed of adjustment from short run to long run is significant. More specifically, the coefficient of the error correction term is -0.5729 meaning that when energy use is above or below its equilibrium level, it adjusts by almost $57 \%$ per year to its equilibrium level. The full convergence process takes about one year and some few months. The result further shows that the one year lag of energy use has positive and significant relationship with the current energy use in the short run. Also, in the short run, the elasticity of electricity consumption (LECON) with respect to energy use is negative and insignificant..

Table 4.9: ARDL bounds testing procedure for economic growth equation (Selected Model: ARDL (2, 0, 0, 0, 0, 0))

\begin{tabular}{|l|l|l|l|l|}
\hline Test statistics & Value & Significant & $\mathbf{1 ( 0 )}$ & $\mathbf{1 ( 1 )}$ \\
\hline F-statistics & 13.94918 & $10 \%$ & 2.08 & 3 \\
\hline & & $5 \%$ & 2.39 & 3.38 \\
\hline & & $2.5 \%$ & 2.7 & 3.73 \\
\hline & & $1 \%$ & 3.06 & 4.15 \\
\hline
\end{tabular}

\section{Source: Computed by author using E-views 10.}

The bound test result presented on table 4.10 shows evidence of a long run relationship between the dependent variable (economic growth) and the independent variables $\left(\mathrm{CO}_{2}\right.$ emission, electricity consumption, energy use, gross fixed capital formation, gross domestic product per capita and labour force). This is proven by the calculated F statistic of (7.0417) which is greater than the critical values of the upper level of the bound (4.15) at $1 \%$ level of significance. since the F statistic exceeds the upper bound of the critical value band, the null hypothesis of no long run relationship between the dependent variable (economic growth) and the independent 
variables $\left(\mathrm{CO}_{2}\right.$ emission, electricity consumption, energy use, gross fixed capital formation, gross domestic product per capita and labour force) is rejected and the alternative retained.

Table 4.10: ARDL long run estimation results for economic growth equation

Selected Model: ARDL $(2,0,0,0,0,0)$

Dependent variable: Economic Growth (LRGDP)

\begin{tabular}{|c|c|c|c|}
\hline Variable & Coefficient & Standard Error & Prob \\
\hline LEU & 0.283289 & 0.181391 & 0.1282 \\
\hline $\mathrm{LCO}_{2}$ & -0.017869 & 0.019020 & 0.3545 \\
\hline LECON & $0.197179 *$ & 0.086384 & 0.0292 \\
\hline LGFCF & $0.376139 * * *$ & 0.0 .034302 & 0.0000 \\
\hline LLF & $-0.348283 * * *$ & 0.047056 & 0.0000 \\
\hline C $($ cons $)$ & 1.569287 & 1.659446 & 0.3514 \\
\hline Obs & 40 & & \\
\hline
\end{tabular}

$* * *$ denote $1 \%, * *$ denote $5 \%$ and $*$ denote $10 \%$ levels of significant

Source: Computed by author using E-views 10.

The long run elasticity of energy use (LEU) with respect to economic growth is positive (0.2832) and this is in conformity with economic a priori expectation. This means that as energy use increases, the real gross domestic product (LRGDP) will also increase. Precisely a 1\% increase in energy use (LEU) will lead to a $0.2832 \%$ increase in real gross domestic product (LRGDP). Also, the long run elasticity of $\mathrm{CO}_{2}$ emission with respect to real gross domestic product (LRGDP) is negative (-0.017869). This means that, there exist a long run negative relationship between $\mathrm{Co}_{2}$ emission and real gross domestic product (LRGDP). This further means that a $100 \%$ increase in $\mathrm{CO}_{2}$ emission will result in $1.7869 \%$ decrease in real gross domestic product (LRGDP). Electricity consumption has a positive long run coefficient of 0.1972 . This is in conformity with our economic a priori expectation. This implies that in the long run, electricity consumption has a positive relationship with real gross domestic product (LRGDP). This further means that an increase in electricity consumption will lead to an increase in real gross domestic product (LRGDP). 


\section{Table 4.11: ARDL Error Correction Regression results for real gross domestic product (RGDP) equation}

Selected Model: ARDL (2, 0, 0, 0, 0, 0) selected based on Akaike Information Criterion Dependent variable is real gross domestic product (RGDP)

\begin{tabular}{|c|c|c|c|}
\hline Variable & Coefficient & Standard Error & Prob \\
\hline D(LRGDP(-1)) & $0.096304 *$ & 0.077666 & 0.2240 \\
\hline CointEq(-1)* & $-0.668120^{* * *}$ & 0.062046 & 0.0000 \\
\hline R-Square & 0.787184 & & \\
\hline Adj R-squared & 0.781583 & & \\
\hline Durbin-Watson & 2.139556 & & \\
\hline \multicolumn{2}{|c|}{ Obs } & 40 & \\
$* * *$ denote $1 \%, * *$ denote 5\% and * denote $10 \%$ levels of significant
\end{tabular}

Source: Computed by author using E-views 10.

The error correction model (ECM) was estimated to see the speed of adjustment to long-run equilibrium due to short-run disturbance. From the results presented on table 4.12 above, the coefficient of error correction term $\operatorname{ECM}(-1)$ is negative and significant at the $1 \%$ level indicating that economic growth, $\mathrm{CO}_{2}$ emission, electricity consumption, energy use, gross fixed capital formation, gross domestic product per capita and labour force are cointegrated. Also, the negative sign coefficient of ecm(t-1) for the selected model indicates the relative speed of adjustment exist to bring the long run equilibrium in the selected model which confirms that the model is corrected from the short run toward the long run equilibrium. More specifically, the coefficient of the error correction term is -0.6681 meaning that when real gross domestic product (RGDP) is above or below its equilibrium level, it adjusts by almost $67 \%$ per year to its equilibrium level. 
International Journal of Social Science and Economic Research

ISSN: 2455-8834

Volume: 05, Issue: 05 "May 2020"

Table 4.12: Diagnostic test for Carbon dioxide $\left(\mathrm{CO}_{2}\right)$ emission equation (ARDL $(1,0,1,2,1,2)$

\begin{tabular}{|c|c|c|}
\hline Test series & Coefficient & Prob \\
\hline Serial Correlation LM test & 2.805401 & 0.0812 \\
\hline Normality Test (Jarque-Bera test) & 1.304778 & 0.520800 \\
\hline Ramsey RESET test & 1.981316 & 0.1607 \\
\hline $\begin{array}{c}\text { ARCH (Autoregressive Conditional } \\
\text { Heteroskedasticity }\end{array}$ & 2.140443 & 0.1266 \\
\hline
\end{tabular}

\section{Source: Computed by author using E-views 10.}

This study conducted a number of diagnostic tests to the ARDL projections in order to ensure that the results are not spurious but meaningful and reliable. The results from the table above shows that the regression results (residuals) do not suffer from serial correlation, heteroscedasticity and the residuals are normally distributed. This is evidence by the low coefficients of the test F-statistics and the fact that these coefficients are not significant at $1 \%$ level of significant. We therefore accept the null hypothesis of no serial correlation, no heteroscedasticity and normal distribution. The Lagrange Multiplier (LM) confirms no serial correlation among the error terms, which means there is no omitted variable bias in the model. Also, the Ramsey's RESET test rejects the any functional misspecification.

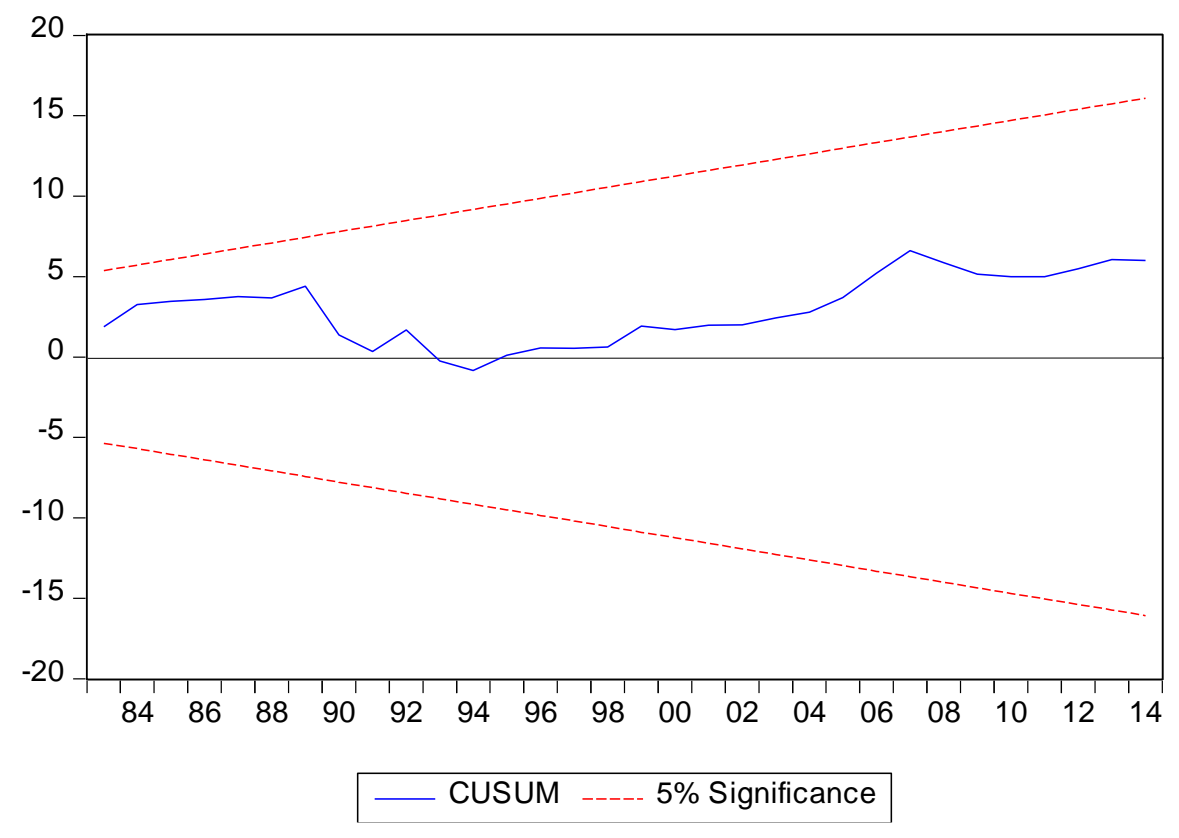

Source: Computed by author using E-views 10. 
Additionally, the test for stability presented on figure 4.9 above also confirms that the model is stable. Furthermore, the CUSUM and CUSUMQ test to the residuals of the estimated errorcorrection model in order to investigate the stability of estimated coefficient both confirms that the model is stable. Therefore, based on the diagnostic test for Carbon dioxide $\left(\mathrm{CO}_{2}\right)$ emission equation (ARDL $(1,0,1,2,1,2)$, we conclude that selected model of ARDL bound testing approach is reliable to examine the determinants of environmental degradation $\left(\mathrm{CO}_{2}\right.$ emission $)$ in Cameroon.

Table 4.13: Diagnostic test for energy consumption equation (ARDL $(1,0,1,2,1,2)$

\begin{tabular}{|c|c|c|}
\hline Test series & Coefficient & Prob \\
\hline Serial Correlation LM test & 3.126856 & 0.0629 \\
\hline Normality Test (Jarque-Bera test) & 3.437432 & 0.179296 \\
\hline Ramsey RESET test & 2.477511 & 0.1286 \\
\hline $\begin{array}{c}\text { ARCH (Autoregressive Conditional } \\
\text { Heteroskedasticity }\end{array}$ & 0.971356 & 0.3888 \\
\hline
\end{tabular}

\section{Source: Computed by author using E-views 10.}

The Lagrange Multiplier (LM) coefficient is small and not significant at $1 \%$ level of significant. This confirms that, there is no serial correlation among the error terms, which means there is no omitted variable bias in the model. The results from the table above shows that the regression result (residuals) do not suffer from serial correlation. Also, the coefficient of heteroscedasticity is small and insignificant meaning that the residuals are normally distributed. We therefore accept the null hypothesis of no heteroscedasticity. Figure 4.13 below shows that the series of the residuals are normally distributed. This is because the coefficient of the Jarque-Bera test statistic is insignificant. Also, the Ramsey's RESET test rejects any functional misspecification meaning that the model is correctly specific. 


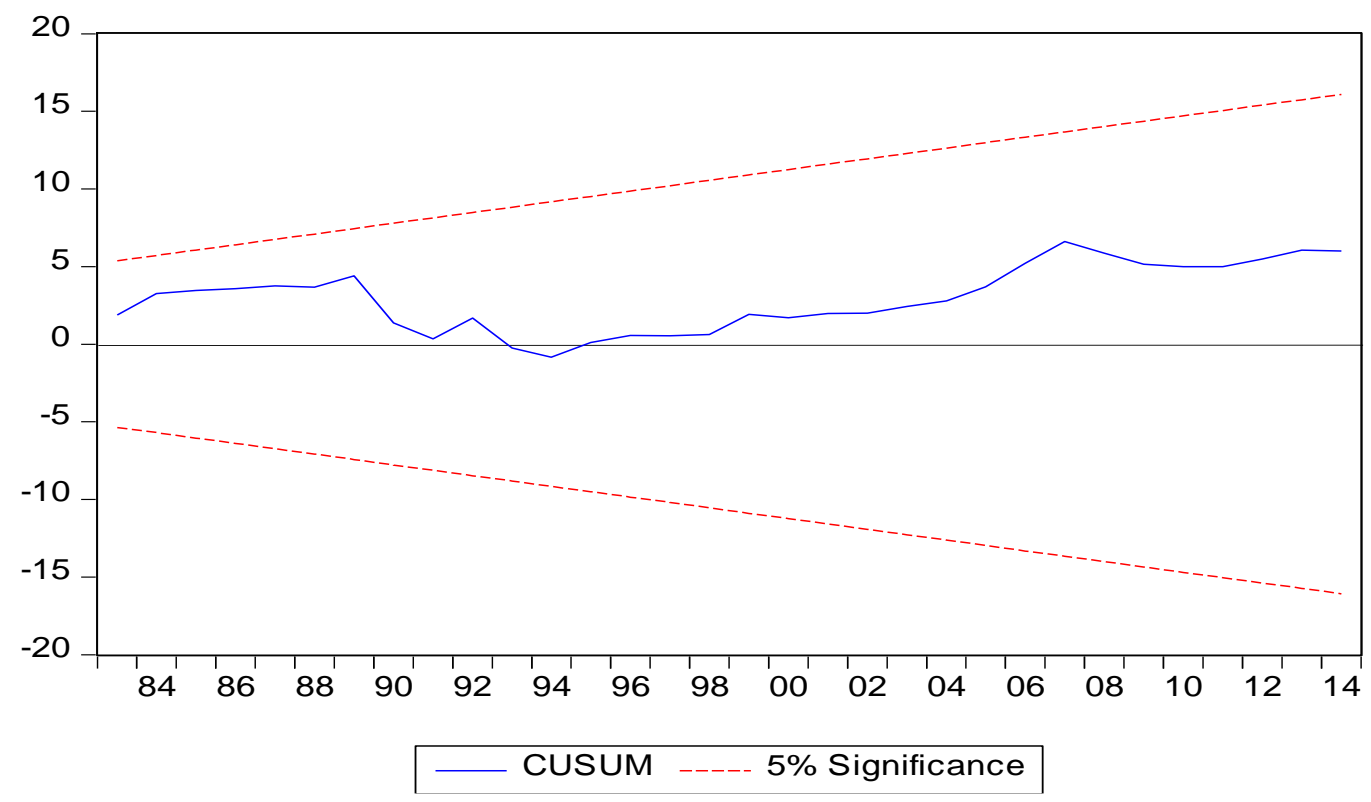

Source: Computed by author using E-views 10.

Additionally, the test for stability presented on figure 4.10 above also confirms that the model is stable. Furthermore, the CUSUM test to the residuals of the estimated error-correction model confirms that the model is stable since the residual line moves within the 5\% bound level of significant. Therefore, based on the diagnostic test for energy equation ARDL $(2,0,2,1,2,1)$. We conclude that the selected model of ARDL bound testing approach is reliable in examining the factors that affect energy consumption in Cameroon.

Table 4.14: Diagnostic test for economic growth equation (ARDL $(2,0,0,0,0,0)$

\begin{tabular}{|c|c|c|}
\hline Test series & Coefficient & Prob \\
\hline Serial Correlation LM test & 2.154717 & 0.1335 \\
\hline Normality Test (Jarque-Bera test) & 3.527660 & 0.171387 \\
\hline Ramsey RESET test & 0.000162 & 0.9998 \\
\hline $\begin{array}{c}\text { ARCH (Autoregressive Conditional } \\
\text { Heteroskedasticity }\end{array}$ & 0.026024 & 0.8727 \\
\hline
\end{tabular}

Source: Computed by author using E-views 10.

The diagnostic test result presented on the table above shows that the Lagrange Multiplier (LM) has a small and insignificant coefficient. This means that, there is no serial correlation among the error term, hence there is no omitted variable bias in the model. The coefficient of the JarqueBera test statistic is insignificant. Meaning that the series of the residuals are normally 
distributed. Also, the coefficient of heteroscedasticity is small and insignificant meaning that the residuals are normally distributed. We therefore accept the null hypothesis of no heteroscedasticity. Again, the coefficient of the Ramsey's RESET test is very small and insignificant, we therefore rejects any functional misspecification meaning that the model is correctly specified.

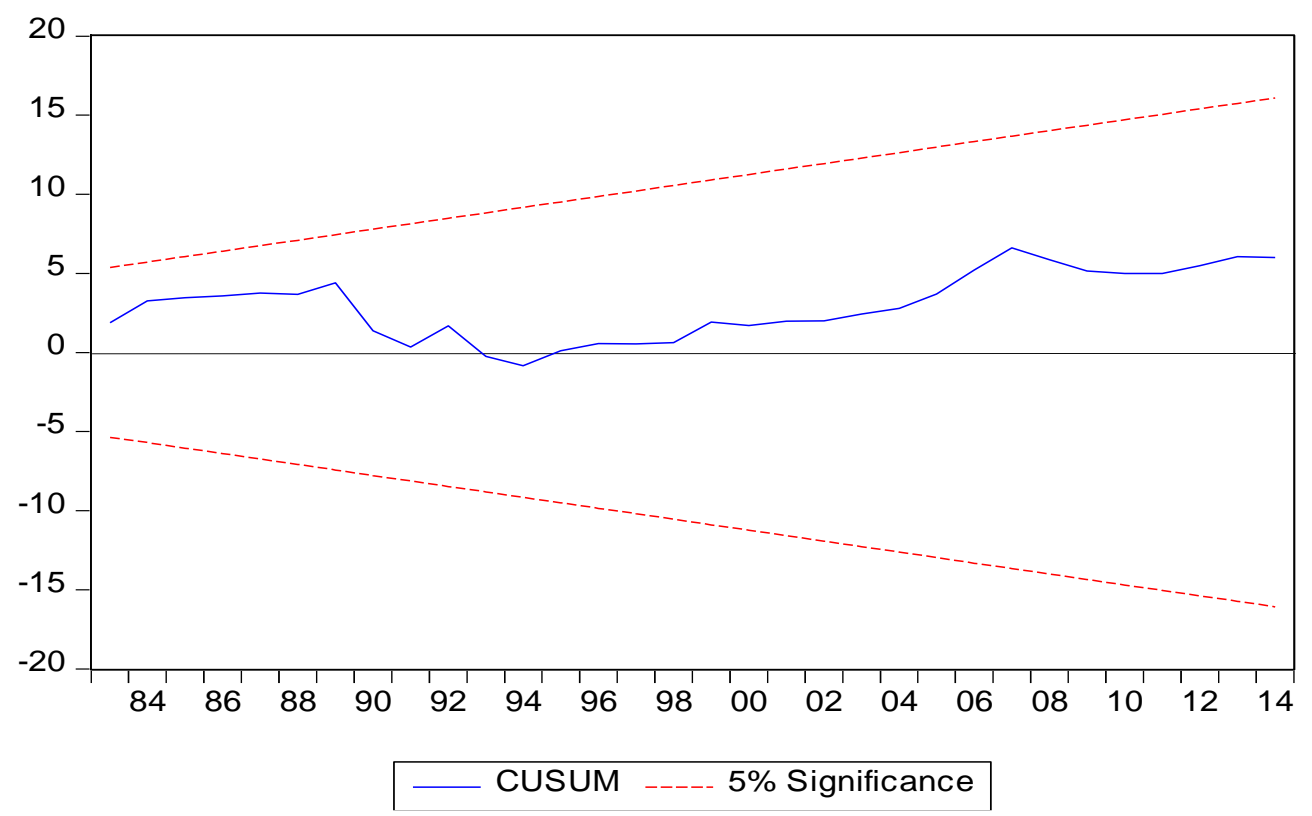

Source: Computed by author using E-views 10.

The figure above shows the CUSUM test to the residuals of the estimated error-correction model. This test confirms that the model is stable since the residual line moves within the 5\% bound level of significant. Therefore, based on the diagnostic test for economic growth equation ARDL $(2,0,0,0,0,0)$. We conclude that the selected model of ARDL bound testing approach is reliable in examining the effect of energy consumption and environmental degradation on economic growth in Cameroon.

\section{POLICY SUGGESTIONS AND CONCLUSION}

Based on the findings derived from this study, it is paramount that the following recommendations be made. The findings of this study revealed energy use (LEU) have a short run and long run positive relationship with economic growth. It is therefore paramount that the government through the Companies in charge of oil refining and transportation should increase the supply of diesel and petrol around the country by connecting the major towns with pipelines. Since the study found that energy consumption is positively related to growth, increasing energy 


\section{International Journal of Social Science and Economic Research}

ISSN: $2455-8834$

Volume: 05, Issue: 05 "May 2020"

supply in an energy hungry nation like Cameroon will have a positive influence on economic growth. Also, the government should invest more in the oil sector by creating more companies to extract and refine crude oil so as to increase the supply of diesel and petrol which positively affects economic growth.

Also, it has been revealed by the study that electricity consumption (hydroelectricity) has a short run and a long run positive relationship with economic growth. Therefore, the government should create more hydroelectric power generating stations by creating more dams or by exploiting its existing "water falls" so as to increase the supply of hydroelectric power. The government could invest in other sources of energy such as solar and wind so as to increase energy supply in the country. Also, Energy infrastructures should be Sustain and enhance. This does not only involve good maintenance practices of existing energy infrastructure but it also deals with ensuring that there is increase in such infrastructure through the issuing of licenses to the private sector for operation of such facilities and by reducing regulatory barriers even to long term capacity contracting. This will encourage many private industries to invest in this sector.

Lastly in the energy sector, the government should increase the budgetary allocation to the sectors and make the release of funds as fast as possible without delays. It is certain that the energy sector is capital intensive and would require huge amount of investments.

\section{REFERENCES}

Akarca, A.T., Long, T.V. (1980). On the Relationship between Energy and GNP: A Reexamination. Journal of Energy and Development, 5, 326-331.

Akinlo, A.E. (2008). Energy Consumption and Economic Growth: Evidence from 11 Sub-Sahara African countries. Energy Economics, 30 (5) 2391-2400

Anjum, A., and Mohammad, S.B. (2001). The Relationship between Energy Consumption and Economic Growth in Pakistan. Asia-Pacific Development Journal, 8(2), 101-102.

Ansgar B., Dreger, C., and Frauke de Haan. (2010). Energy Consumption and Economic Growth: New Insights into the Cointegration Relationship. Ruhr economic papers, 190, $1-24$.

Asafu-Adjaye, J. (2000). The Relationship between Energy Consumption, Energy Prices and Economic Growth: Time series evidence from Asian developing countries. Energy Economics, 22(6), 615-625 
International Journal of Social Science and Economic Research

ISSN: 2455-8834

Volume: 05, Issue: 05 "May 2020"

Asongu, S. A. and G. Rangan (2015). "Trust and Quality of Growth", African Governance and Development Institute Working Paper No. 15/026, Yaoundé.

Bayode, O. J., Emmanuel, A. A. \& Sogbon O. (2011). Environmental implications of oil exploration and exploitation in the coastal region of Ondo state Nigeria: A regional planning appraisal. Journal of Geography and Regional Planning. Vol. 4 (3) pp 110 121.

Brock, William, and M. Taylor. (2010), The Green Solow model. Journal of Economic Growth 15 (2): $127-153$.

Chang CC (2010), "A multivariate causality test of carbon dioxide emission, energy consumption and economic growth in China", Applied Energy, 87, pp. 3533-3537

Cheng, B. S., and Lai, T. W. (1997). An Investigation of co-integration and Causality between Energy Consumption and Economic Activity in Taiwan. Energy Economics, 19(4), 435444.

Chibuzor Azodo (2018) "Grow First Then Clean Later": Environmental Degradation, Economic Growth and Energy Consumption in Nigeria

Gbadebo, Olusegun, O., and Chinedu, O. (2009). Does Energy Consumption Contributes to Economic Performance: Empirical Evidence from Nigeria. Journal of economics and international finance, 1(2), 044-058.

Holtz-Eakin D., and Selden T.M. (1995), Stoking the fires, $\mathrm{CO}_{2}$ emissions and economic growth. Journal of Public Economics 57 (1) (mai): 85-101.

International Energy Agency. 2008. CO2 Emissions from Fuel Combustion 1971-2006. OECD/IEA, Paris, France.

Jean Gaston Tamba (2017) Energy consumption, economic growth, and CO2 emissions: Evidence from Cameroon, Energy Sources, Part B: Economics, Planning, and Policy, 12:9, 779-785, DOI: 10.1080/15567249.2016.1278486

Khalid Alkhathla, Muhammad Qaiser Alam and Muhammad Javid, 2012) "Carbon Dioxide Emissions, Energy Consumption and Economic Growth in Saudi Arabia: A Multivariate Cointegration Analysis" British Journal of Economics, Management \& Trade 2(4): 327339. 


\section{International Journal of Social Science and Economic Research}

ISSN: $2455-8834$

Volume: 05, Issue: 05 "May 2020"

List, J. A. and C. Y. Co. 2000. The effects of environmental regulations on foreign direct investment, Journal of Environmental Economics and Management, 40, 1-20.

Menyah, K., Wolde-Rufael, Y., 2010. Energy consumption, pollutant emissions and economic growth in South Africa. Energy Economics 32, 1374-1382.

Mohammed, A., Ismat, A., Jeroen B. and Guido V. H. (2012). Energy Consumption, Carbon Emission and Economic Growth Nexus in Bangladesh: Cointegration and Dynamic Causal Analysis. Energy Policy. Vol. 45, 217 - 225.

Olusegun, O.A. (2008). Energy consumption and Economic Growth in Nigeria: A Bounds Testing Co-inntegrative Approach. Journal of Economic Theory, Vol. 2(4), pp.118-123

Ongono, P. (2009). Energy consumption and economic performance in Cameroon. MPRA Paper No. 23525.

Saboori, B., Sulaiman, J., 2012. Environmental degradation, economic growth and energy consumption: Evidence of the environmental Kuznets curve in Malaysia. Energy Policy 60, 892-905.

Sharma, S. S. (2011). Determinants of carbon dioxide emissions: Empirical evidence from 69 countries. Applied Energy, 88, 376-382.

Uddin Mirza Md. Moyen, and Md. A. Wadud (2014), "Carbon emissions and economic growth of SAARC countries: A Vector Autoregressive (VAR) Analysis", International Journal of business and management Review, Vol 2, No 2, pp. 7-19.

Wolde-Rufael, Y. and Kojo M. Y. (2010). Energy Consumption, Pollutant emission and Economic Growth. Energy Policy, Vol. 32 1374-1382. 